\title{
The Derg-SPLM/A Cooperation: An Aspect of Ethio-Sudan Proxy Wars
}

\author{
Regassa Bayissa*
}

\begin{abstract}
The warm and friendly Ethio-Sudan diplomatic relations that followed Sudan's independence in 1956 and the long standing frontier trade between the two countries have been severely damaged by the outbreak of civil wars in southern Sudan in 1955 as well as in Eritrea in 1962. As the civil wars intensified in both countries, the influx of refugees and insurgents across their common border took place. Internal political and socio-economic problems in Ethiopia and the Sudan, together with super-power rivalries in the Horn brought about periods of increasing hostilities between the two countries. On a tit for tat basis, both the Imperial and military governments of Ethiopia and the successive governments of the Sudan came to encourage and assist cross-border guerrilla forces from either side. Thus, animosity rather than cooperation characterized relations between the Sudan and Ethiopia until the fall of the Derg in 1991.
\end{abstract}

Keywords: Derg, Ethio-sudan relations, SPLM/A, proxy wars

\section{Introduction}

The Upper Nile and Jonglei regions of Southern Sudan bordering Gambella and the Gambella region itself were intensively affected by the wars between the governments of the Sudan and the Anyanya I (the southern Sudan Guerilla group in the first civil war 19551972), the SPLA (Sudan People's Liberation Army of the second civil war 1983-2005), the Lou-Jikany conflict (1993-1994), the armed conflicts following the splits within the SPLM/A and the South Sudan Independence Movement Army (SSIM/A) 1991-2005). The Sudan governments claimed that Ethiopia was supporting the South Sudan guerrillas struggling to secede from the north while the governments of Ethiopia accused successive Sudanese governments of material and moral support to the Eritrean secessionist movements.

\footnotetext{
* Assistant Professor, College of Commerce, Addis Ababa University
} 
The military government of Ethiopia (the Derg) accused the Sudan of supporting the insurgents of northern Ethiopia and of its hostile policies towards the Ethiopian revolution and national unity. The Derg provided the SPLA with substantial military and logistical support in its struggle against the Khartoum regime which hosted the opposition movements from Ethiopia. It also provided the SPLM/A with supply routes, training facilities, a radio station, and sites for the establishment of refugee camps in the Gambella region ran by the UNHCR. The SPLA repaid the assistance from Ethiopia by fighting proxy wars for the Derg against the OLF (the Oromo Liberation Front) and the GPLM (the Gambella People's Liberation Movement). Both movements were based in the Sudan and launched guerrilla wars against the Derg and SPLA from the Upper Nile and Blue Nile. Similarly the Sudan Government used the Ethiopian opposition groups in fighting the SPLA in Gambella. The Akobo and Jikawo border districts of Gambella were under continuous attacks from the GPLM and the Sudanese armed forces. Moreover, the Sudanese army had also supported the 1989-90 EPLF-OLF coordinated invasion and prolonged occupation of Assosa. These regional conflicts and proxy wars brought about further violence and deterioration of economic, social and political conditions of the EthioSudan communities.

The Derg played an important role in the establishment of the SPLM/A which it logistically and militarily supported and used against its opposition groups operating from the Sudan. Ethiopia and the Sudan used internal conflicts to fulfill their own strategic objectives. These conflicts have adversely influenced their relations and intensified the misery and suffering of their peoples. The data for this research was based on military intelligence reports of the archives of the Ministry of Defence, secondary sources and oral information collected during my fieldworks in Gambella as part of my $\mathrm{PhD}$ research from 2005 to 2009.

\section{The Foundation of SPLM/A in the Gambella Region}

President Numeiri's abrogation of the 1972 Addis Ababa Agreement was the main cause for the rise of the SPLM/A and the eruption of the second civil war in southern Sudan. In 1983 Numeiri's regime destroyed the Southern Regional Government and Assembly and divided the region into three provinces. The government also declared the policy of transferring the Anya Nya guerilla forces which had been integrated into the national army to the North while the Addis Ababa Agreement stipulated that they were to serve only in the South. The southern battalions stationed at Akobo, Bor, Pibor, Pachalla and other garrisons revolted against the new policies of the government. The imposition of the Islamic Laws further led to widespread opposition and desertions in Bor, Pibor and Pachalla garrisons led by famous commanders such as Major Karubino Kuanyin, Captain David Reik, Major William Nyuon, Lieutenant Vincent Kuany and Corporal Bol Kur who joined the exodus of thousands of refugees from Upper Nile and Jonglie to the bordering 
Gambella region of Ethiopia. In response to the abrogation of the Addis Ababa Agreement and repressive measures of the government, the South Sudanese of different walks of life joined the liberation struggle and according to Peter A. Nyaba (1997: 54) they:

...trekked all the way to the Ethiopian borders where the first SPLM/A camps were established. Even. the question of the name of the Movement, its political direction and leadership were only resolved after the arrival in western Ethiopia of the politicians, military officers and men, students, farmers, cattle herders, workers and others, who comprised the rank and file the movement.

There were some Anya Nya officers who resisted the Addis Ababa Agreement and remained in Ethiopia. These officers formed the Anya Nya II group known as the Sudan People's Revolutionary party (SPRP) composed of ex-Anya Nya Nuer, who negotiated some funds from Libya with Ethiopian help. The Anya Nya II groups operating in South Sudan gained support from the Southern soldiers and civilians (Johnson 2003: 84). The inundation of the Gambella region by armed mutinous, southern forces from South Sudan was a serious security concern for Ethiopia. From 10-18 June 1983, the committee of high level Derg officials led by Fisseha Desta toured the border districts of Gambella region by helicopter with the main objective of bringing together the refugees scattered all over the border districts of Gambella and put them in refugee camps. For this goal the Ethiopian officials searched for the mutinous army officers who took refuge in Gambella so that they could help them to organize the refugees into residential camps. The officials also wanted to know the conditions in South Sudan which forced thousands of Sudanese to migrate to Gambella. The members of the committee visited Itang, Belpam, Adura, Jikawo and Akobo. In Itang the committee met the South Sudanese refugees and was informed that it was Dr. Colonel John Garang who could give a detailed explanation of the problem in South Sudan in general and the refugee issues in particular. The committee members went to Adura and picked Dr. Colonel John Garang Mabior, a Dinka intellectual, Akwot Atem, a Dinka veteran, Samuel Gai Tut, a Nuer Anya Nya officer, Captain Salva Kiir who was a Dinka security officer in Malakal, William Chul Deng, and Bol Kur as influential refugee leaders and returned to Gambella town. ${ }^{1}$

In Gambella the Ethiopian officials and the aforementioned South Sudanese refugee leaders and officials of the Southern Regional Government, met for three days and discussed different issues in relation to the South Sudanese insurgency. The issues predominantly revolved around: the causes of the current South Sudanese revolt, the previous revolts and their failure, and relations between the present movement and other opposition groups in the Sudan. The Ethiopian officials also wanted to know the political agenda of the mutinous army officers and South Sudanese government officials in their opposition to the Khartoum regime, and indicated that the arrival of such a huge number of armed officers and soldiers into the Gambella region of Ethiopia was a violation of international border and international law. The Ethiopian officials also requested the South Sudanese refugee leaders to identify the number of South Sudanese refugees and their

1 Ministry of National Defence Archives, . .113, . 492 . 
locations in Gambella. The refugee leaders were told to indicate the number and kinds of weapons in the hands of the refugees; and to report their political objectives, and whether they have a political movement (party) or not. ${ }^{2}$

In their response to the Ethiopian officials' questions the refugee leaders explained that the root causes of the movement were oppression and exploitation of the various nationalities of the Sudan by successive regimes from Khartoum. According to these leaders, the violation of the Addis Ababa Agreement, the encroachment of the regime on the main economic resources of the south (oil, water and agricultural lands), the integration agreement and joint defense treaty with Egypt without consultation and participation of the people of South Sudan and the policy of transferring to the north of the absorbed Anya Nya I guerrillas, which precipitated the May uprising, (but the Addis Ababa Agreement stipulated that they were to serve only in the South), were mentioned as the main factors that led to the southern insurrection and the second civil war. The leaders of the movement also identified that their ideology was to establish a 'United Socialist, New Sudan', not a separate independent South Sudan. ${ }^{3}$ The movement sought to obtain intellectual, moral, military and other material assistance from the socialist countries like Ethiopia sympathetic to the aims and objectives of the movement. The high level Ethiopian officials questioned the rebel leaders on the atrocities and lack of discipline of the South Sudanese refugees in Gambella, which the memo of the Ministry of Defence stated as follows:

Your refugees in Ethiopia were not properly registered in accordance with the UN regulations, they violate Ethiopian law, they plunder (the local people), they interfere in (the local) administration. What is your opinion about this? (Answer) We have already heard the plundering and illegal activities of the refugees, and we are disappointed. A man would not have destroyed his own house. We consider these people as destroyers of their own houses. All these deeds are the outcome of lack of awareness. We will correct...The Ethiopian problem is our problem. Soon we will separate the fighting forces from the aidreceiving refugees. Give us directives and we will implement them... ${ }^{4}$

The Anya Nya I had military training bases at Jikawo, Itang, Belpam and Teilet until the Addis Ababa Agreement which was known to the government of the Sudan. The Ethiopian officials suggested that for the new movement proper leadership should be created and its base to be established in the interior away from possible threat of the Sudanese army and security. ${ }^{5}$ The prominent refugee leaders who met and discussed with

\footnotetext{
${ }^{2}$ MOND, . . 131, Minutes of Conference of Ethiopian officials with South Sudanese refugee leaders.

${ }^{3}$ MOND, . .131, Minutes of Conference of Ethiopian Officials and South Sudanese Refugee Leaders in Gambella, 22 April 1983, Informants David Odoro, Cham Ujulu. David is an Anuak of Gambella and was governor of Itang district who witnessed the SPLA activities and atrocities in Gambella region.

${ }^{4}$ Ibid.

${ }^{5}$ Ibid.
} 
the Ethiopian officials at Gambella asked for some weapons to defend themselves, basic needs for maintenance, education for children of refugees and they suggested that their leader, John Garang to present himself secretly to Colonel Mengistu Haile Mariam and receive directives and encouragement. The Ethiopian officials positively responded to these requests and all the five leaders of the new movement were brought to Addis Ababa for political orientation. Women, children and the elderly refugees were to be registered and assisted by the UN agencies in refugee camps which would reduce the burden of the government and the local population. They also agreed that the young male refugees were to be recruited for guerrilla force and military training camps were to be prepared in the interior away from the common border. ${ }^{6}$

Thus the leadership of the clandestine cell of the new South Sudanese Movement came into being during the 18-26 June 1983 high level Ethiopian officials' meeting with the influential South Sudanese refugee leaders in Gambella. The five leaders served in different government structures, and had different political views on the problem of South Sudan. Akwot Atem was one of the guerrilla leaders operating from Ethiopia who did not accept the Addis Ababa Agreement of 1972. Three former Anya Nya officers who had served together in the Upper Nile, namely, Colonel John Garang, head of the Staff College in Omdurman, retired Major William Abdellah Chuol and Samuel Gai Tut, a minister in the interim Southern Regional Government (in 1982), made contact with Akwot Atem. Another ex-Anya Nya officer, Major Kerubino Kuanyin Bol, had been engaged in fighting Anya Nya II, also made contacts with them before the events of May 1983 in Bor (Johnson 2003: 60).

During their stay in Addis Ababa the leaders of the new movement made a division of labor among themselves; accordingly, Akwot Atem became Chairman; John Garang, a military organizer; and Samuel Gai Tut and Joseph Ahur Ujio members of the Political Council. They named the new movement as the Sudan Peoples' Liberation Movement (SPLM), and the military wing of the movement as the Sudan Peoples' Liberation Army (SPLA). They prepared a manifesto of the movement and declared socialism to be their ideology. The manifesto of the emerging SPLM/SPLA made a blow to the northern elite's accusations against the southerners, that they were separatists. In the Manifesto of the Sudan People's Liberation Movement of 31 July 1983, the SPLA/SPLM leaders stated: "It must be reiterated that the principal objective of the SPLA/SPLM is not separation of the South. Africa has been fragmented sufficiently enough by colonialism and neocolonialism and its further fragmentation can only be to the interest of her enemies."7 As to why the liberation movement for the whole of Sudan originated in South Sudan and by southern Sudanese political and military leaders, John Garang, chairman and commander-in-chief of the SPLA/SPLM made the following remarks in his first official appeal to the Sudanese people:

\footnotetext{
${ }^{6}$ Informants David Odoro, Cham Ujulu. (07 February 2007).

${ }^{7}$ John Garang de Mabior, Manifesto of the Sudan People’s Liberation Movement, July 31, 1983, Cited in Elias Nyamlell Wakoson, The Sudanese Dilemma: The South-North Conflict, Northeast African Studies, Volume 9, Number 3, 1987, 43-58.
} 
The burden and incidence of neglect and oppression by successive Khartoum clique regimes had traditionally fallen more on the South than on other parts of the country. Under these circumstances, the marginal cost of rebellion in the South became very small, zero or negative; that is, in the South it pays to rebel....(the clique in Khartoum)...has openly aggressed and agitated Southern Sudanese into rebellion and civil war....it is clear and natural that a Vanguard Movement for the liberation of the whole Sudanese people had to have its origins in South Sudan. Any armed struggle must have as its point of departure the immediate and genuine needs and demands of the masses of the people. ${ }^{8}$

On their return to Gambella, the SPLM/A leaders were given directives by the Ethiopian authorities to execute the responsibilities given to them. The refugees were settled at Itang, Belpam and Rukedy camps and were briefed on the objectives of the movement by their leaders. Competent individuals from the refugees were assigned into the designed political and military structure of the movement. The leaders prepared criteria of registration and recruitment for the fighting force of the movement. They were given directives to set up a recruitment committee for the training of guerrilla forces. ${ }^{9}$

\section{The Early SPLM/A Leadership Crisis}

The military government of Ethiopia (the Derg) which accused the Sudan of supporting the insurgents of northern Ethiopia and of its hostile policies towards the Ethiopian revolution decided to use the southern Sudanese opposition to topple Numeiri's regime. Therefore, the Ethiopian officials were very eager to see the beginning of training of the fighting forces and the first SPLM/A leaders had gathered the refugees and briefed them about the movement, its program and manifesto from 16-18 August 1983. There was a long delay of the recruitment because of the rise of apparent power struggle over leadership of the emerging movement between Akwot Atem and John Garang. ${ }^{10}$ Garang was arming Akot Atem, the prominent Anya Nya II commander operating from Ethiopia, through the two Anya Nya II Nuer officers, Samuel Gai Tut and William Abdallah Chuol. The mutinous officers of 1983, Kerubino Kuanyin Bol (a Dinka) and William Nyuon Bany (a Nuer) preferred John Garang for the leadership to the two Anya Nya II officers. The older Anya Nya commanders, Samuel Gai Tut and Akot Atem, however, felt that their former seniority over Garang should be retained. They also preferred the separation of the military from the political wing of the movement and proposed Gai Tut as the head of the military wing and

\footnotetext{
${ }^{8}$ John Garang de Mabior, Appeal to the Sudanese People on the Founding of the Sudan People's Liberation Army (SPLA) and Sudan People's Liberation Movement, (1983) Cited in Elias N. Wakoson, The Sudanese Dilemma, The South - North Conflict, Northeast African Studies, Volume 9, Number 3, 1987, 43-58.

${ }^{9}$ MOND, .131, 22 April 1983. Minutes of Conference.

${ }^{10}$ MOND, .131, 22 April 1983. Minutes of Conference, Informants, David Odoro, Cham Ujulu, Captain Bekele Baddadda.
} 
Akot Atem as the head of the political wing. They offered the post of deputy commander to Garang (Johnson 2003 65).

On 24 August 1983 sixty refugee representatives from Itang, Belpam and Rukedy refugee camps formed a committee to elect the chairman of the SPLM/A under the leadership of William Chuol Deng. Akwot Atem and Samuel Gai Tut were identified as candidates. But Samuel Gai declined the candidacy and Akwot Atem was elected without a contender. Immediately after the election Akwot Atem gave appointments. Samuel Gai Tut was assigned as the head of the military committee of the movement, the position previously given to John Garang, who was now posted as the chief of staff of the SPLA; Joseph Oduho, the head of the foreign affairs and Martin Majic the head of the judiciary. ${ }^{11}$ The election and the appointment severely divided the leadership of the emerging movement into two opposing groups. John Garang refused to accept the vague position of chief of staff of the SPLA given to him as well as the result of the election. ${ }^{12}$

In July 1983 the Ethiopian Military Government set up an ad-hoc committee at the centre to resolve the problem within the leadership of the SPLM/A in cooperation with the regional and local officials of Illu Ababor and Gambella. The committee made several visits to Gambella. The committee believed that there was no need for Akwot Atem to arrange the election of the leader of the movement by the refugee population because at the meeting with the refugees, there was no opposition to his leadership. The refugee representatives from different refugee camps in Itang and Belpam had unanimously accepted the manifesto and program of the movement. Therefore, the government committee had increasingly become skeptical of the re-election of Akwot Atem. Finally, after the committee discovered that the objective of electing the leader by the refugees was to legitimize and strengthen the power of Akot Atem. ${ }^{13}$

Akwot Atem and Samuel Gai Tut who were long time close friends with similar political views grew anxious of the increasing popularity of John Garang. Garang was not only a man of higher academic and military training but was also believed to have founded the clandestine cell of the emerging movement in the Sudan's armed forces. His radical principles in the manifesto and program of the new movement appeared to be a serious threat to the future power positions of the Anya Nya old guards. Furthermore, Akwot Atem sought the support of the majority Nuer refugee population in Itang and Belpam through his Nuer friend, Colonel Samuel Gai Tut. The local government officials of Gambella Awraja (the administrator, the head of the Public Security and the commanding officer of the Gambella military garrison) reported to the higher authorities that the five leaders of the SPLM/A were requested to meet and draft a work plan to execute the program of the movement. But the leaders could not agree to meet because of serious divisions among them and informed the regional officials to report the problem to the higher officials. On 27

\footnotetext{
${ }^{11}$ The last two did not accept the appointment.

${ }^{12}$ MOND, .492, Report on the Crisis of Leadership in South Sudanese Movement, 30 August 1983.

${ }^{13}$ Informants: David Odoro, Tuwol Okelo, Ujun Ujulu ( 07 February 2007), MOND, .492, Report on the Crisis of Leadership in South Sudanese Movement, 30 August 1983.
} 
August 1983 the team of Illu Ababor Regional and Gambella Awraja officials left for Itang to investigate and end the divisions. ${ }^{14}$

The team of Ethiopian officials and the SPLM/A leadership met and discussed issues of resolving the problem of the leadership by democratic means. The main focus of their discussion was on power sharing in leadership of the movement, particularly whom to assign to lead the SPLA, the military wing of the movement. The committee requested Colonel Samuel Gai Tut to resign from the leadership of the military committee and accept the position of the vice-chairman and the head of the administrative committee of the movement. This was an attempt to bring back John Garang to the chairmanship of the military committee. But Samuel Gai Tut refused to accept any other position except the leadership of the military wing of the movement. The joint meeting of the Ethiopian officials and the SPLM/A leaders reached an agreement that Akwot Atem should remain the chairman of the movement. But the question of the military committee head and the commander of the SPLA remained unresolved. Akwot Atem continued to defend the appointment of Samuel Gai Tut as the organizer of the military committee. He argued that Samuel Gai Tut was a long time, well known and strong military leader, and his Nuer origin was very important because they had planned first to liberate the Upper Nile, the region with the majority of the Nuer population. ${ }^{15}$

\section{The Rise of John Garang as Chairman and Commander-in-Chief of the SPLM/A}

To make further investigation and to solve the leadership problems of the South Sudanese movement, the aforementioned government committee selected fourteen popular personalities from the refugees to collect more information. Accordingly, three military officers, four refugee camp leaders, four highly experienced ex-officials, and three people of higher education were picked to find a solution of the leadership crisis. Thirteen people favored John Garang for the leadership of the movement, while the remaining four supported Akwot Atem. John Garang was supported by educated officers and most refugee leaders. The opponents of John Garang accused him of representing only the Dinka interests and of being a CIA agent sent by President Numeiri to eliminate the movement and has come to divert the orientation of the movement to western capitalism because he was educated in the USA. ${ }^{16}$

Among the prominent personalities who forwarded their opinions was Martin Majic, the Dinka lawyer who suggested that for the political leadership of the movement, people should be identified and given political training in Ethiopia and Garang should be given the post of military leadership and he should start recruitment and training of the fighting forces. Another important figure was Major Kerbino Kuanyin, who explained that the program of the new movement was drafted by John Garang. The investigation committee concluded that there was a disparity of political orientation between the different groups,

\footnotetext{
${ }^{14}$ Informants: Samuel Gilo, David Odoro.Cham Gutlak. (08 February 2007)

${ }^{15}$ MOND, . 492, Report on the Crisis of Leadership in South Sudanese Movement, 30 .August 1983.

${ }^{16}$ Informants: Kuwot Utuwo, David Malwal. (Februay 08, 2007).
} 
mainly between the Anya Nya II leaders and the progressive individuals organized around John Garang and therefore it recommended that they should be taken to Addis Ababa for political education. The committee reported to the Derg Office that the urgent task was the recruitment, training and organizing of the fighting forces. The regional officials anticipated that the lack of unity among the refugees, particularly the growing tension and hostility among the armed groups of refugees led by rival leaders might escalate to factional fighting and endanger the security of the Gambella region. They strongly recommended forging unity of the south Sudanese refugees under one leadership and to speed up the creation of a fighting force. The tasks and responsibilities of the various committees indicated in the program of the movement were to be clearly identified and handled by competent people. ${ }^{17}$

Nevertheless, the attempt to forge a common forum was frustrated, because Akot Atem and Samuel Gai Tut, as the senior officers of the Nnya Nya were anxious of the rising popularity of John Garang, who was the Anya Nya junior officer. Hence each leader gathered supporters and sought Ethiopian endorsement. These maneuvers ended in bloodshed, followed by the withdrawal of Anya Nya II forces and their prominent leaders back into the Sudan. John Garang emerged as the leader of the SPLM/A. Garang's charismatic disposition, radical political views and sound academic and military background greatly attracted the attention of the Ethiopian officials. Therefore, with the support of the Ethiopian government Garang began to openly oppose every activity of his rival Anya Nya II leaders in Itang. According to Major Samuel Gai Tut, “....it became clear later on that he (Garang) did not do this alone but had initially the implicit and eventually the explicit support of the Ethiopian government."18

The Derg imposed unity on the different groups in south Sudan that sought its shelter and support, and backed John Garang as the leader of the new movement who, according to Peter Wood, “...combined ideological and military leadership in a way unprecedented in Sudanese politics since Mohamed Ahmed el-Mahdi in the nineteenth century.” (Woodward 2003: 97) Ethiopia quickly supported Garang's view of a radically changed, united 'New Sudan' rather than the old Anya Nya struggle for the secession of the South, a position suitable for the regime in Ethiopia which was fighting against the northern secessionist movements (Johnson 2003: 64).

The Anya Nya II leaders, including Akwot Atem and Samuel Gai Tut were told by the Ethiopian officials to integrate their forces into the forces of John Garang. The Ethiopian army in charge of the south Sudanese refugees in the Gambella region moved to Itang to execute the order. Akwot Atem, Samuel Gai Tut and other Anya Nya II leaders were overwhelmed and had no choice but to withdraw from Itang to Tiergot, the border territory in Gambella. Later on they contacted the Ethiopian authorities at Tiergot and made a last attempt to come back to Itang to bring about a dialogue for reconciliation and unity between their faction and that of John Garang. Their attempt failed because Garang who was confident of Ethiopian support ignored reconciliation and fierce factional fighting followed thereafter. The followers of Garang, with the support of the Ethiopian army

${ }^{17}$ Informants: Alemayehu Chekol, David Odoro, Cham Gutlak. (08 February 2007).

${ }^{18}$ MOND, ...492, Samul Gai Tut “Statement to All Sudanese”. 
invaded Belpam, the headquarters of Anya Nya II, and defeated the supporters of Samuel Gai Tut, Akwot Atem and William Abdella Chuol, and many people were killed. ${ }^{19}$ According to Sharon Hutchinson, "Forging tight alliance with Mengistu, Garang adopted the heavy-handed militarism and autocratic leadership style of his Soviet-supported hosts. He proceeded to hunt down his Anya Nya II rivals, who swiftly fled back to Sudan....”On the other hand quickly supporting Garang's view of a radically changed, united 'New Sudan' and "fighting his own war against secessionist rebels in Eritrea and Tigray, Mengistu could hardly have been expected to support the main political objective of the Anyanya II.”(Hutchinson 2001: 307-331).

In March 1984 the officials of Illu Ababor Region decided that the Anya Nya II leaders and their followers had to hand over their weapon to John Garang or to the Ethiopian authorities. But the defiant Anya Nya II leaders retreated to their bases in the Sudan. The failure of further attempts at reconciliation and the killing of Samuel Gai Tut in March 1984 by Kerubino's forces on the border while trying to come to Ethiopia to negotiate with the SPLM/A led to an alliance of Anya Nya II with Numeiri (Johnson 2001: 7). According to Nyaba, when the SPLM/A raised the façade of a 'United Socialist Sudan' as its objectives, "...it found a ready and willing ally in Ethiopia". The Ethiopian authorities were from the very beginning interested in supporting armed resistance against the Khartoum regime, and the emergence of the SPLA blended well into their strategic calculations. The support given by the Ethiopian regime to the military officers, and the subsequent rise of a political military High Command, the highest organ of the SPLM/A, comprising solely former military officers of the Sudanese army indicated the militarist trend the Ethiopian regime had wanted the infant movement to follow. This sowed the seeds of division and dichotomy between the military officers and the politicians and the intellectuals in general, who came to Ethiopia to join the armed struggle. They were ignored, marginalized and persecuted and branded as 'bourgeois', the potential or real enemies of the people. The Ethiopian officials and some South Sudanese looked for a competent military officer to lead the armed struggle in south Sudan. John Garang's academic and military credentials combined to make him the best qualified and suitable candidate for the leadership of the SPLM/A (Nyaba 1997: 34-5) However, Nyaba argued that the considerable role of the Derg on the establishment of the SPLM/A and the dependence of the Movement on the Ethiopian material and military support was more of a liability than an asset for the Movement (Nyaba 1997: 33)

Whatever the assistance rendered to the infant movement, the involvement of the Ethiopian regime in the affairs of the SPLM/A from the very beginning seriously injured and distorted its growth and development. It prevented the emergence of an internal political and democratic culture nurtured by internal political debate and ideological struggle that could have cleansed the infant movement and its combatants of the filth of the 'old Sudan'.

${ }^{19}$ MOND, . 492, Report of Leadership Crisis in South Sudanese Movement, 30 August 1983, Peter Armound Nyaba, The Politics of Liberation, p.34. 
Personal relations between Mengistu and John Garang and the SPLM/A's close association with the pro-Soviet Derg regime was used in the propaganda of the Khartoum regime to brand the movement as a communist and to get support from the Arab countries. However, the supply of immense military and logistical support to the SPLA by the Derg and the use of a strategic Gambella rear base played decisive role in the military advances of the movement in the 1980s.

\section{The Derg's Military and Logistical Assistance to SPLA}

The Ethiopian military government's all rounded support to the SPLM/A in order to weaken the Numeiri regime and the opposition movements in the Sudan had strengthened the military muscle of the SPLM/A which gradually enabled it to control different groups in southern Sudan. The archives of the Ministry of National Defense clearly indicated that the SPLA led by Garang was from the very beginning under close leadership, supervision and support of the Ministry of National Defense of Ethiopia. Among other things, the Ministry of National Defense Archives revealed that the Ethiopian military officials had planned and participated in the SPLA's war strategy in South Sudan:

With the close leadership and support of Comrade (Defense) Minister within a short period the 07 Project (the SPLA) has become a well known movement. The First Division is trained and armed. It is establishing a base in South Sudan and ready for combat. The Second Division will complete its training after four weeks and will be deployed. The Third Division is under preparation to enter the training camp....Conditions are getting favorable since community leaders, soldiers and students are traveling long journey and coming to join the SPLA.... South Sudan is a vast territory with a scattered armed struggle. This condition compelled the division of South Sudan into six operational zones. It has become necessary to deploy forces into the different zones and to closely follow, lead and control conditions for military operation. ${ }^{20}$

The Ethiopian assistance was not limited to the supply of fuel, provisions, medicine and logistics only, but the well qualified Ethiopian officers and Air Borne commandos also provided intensive military training for thousands of SPLA guerrilla fighters at different SPLA military camps in western Ethiopia. A memo of the archives of the Ministry of Defense reads:

Within a year of its establishment, (SPLA) has scored a significant achievement in crushing Numeiri's forces in south Sudan. Generally it is supported by Ethiopia and Libya gave some assistance in weapons. So far 20,000 fighting forces were trained by selected members of the Air Borne Division and 7000 of

${ }^{20}$ MOND, .691, 10/N25/ /1/7/76, December 5, 1983. 
them are waiting for weapons to join the fighting force. In addition, by the order from the higher authority, 400 cadets participated in the training of officers. 20 of them were dismissed because of low performance and disciplinary reasons, while the 380 had completed the officers' course and graduated on September $23,1984 .^{21}$

In his SPLM/SPLA military and political program for the year May 1987 to May 1988, Col. Dr. John Garang de Mabior, Chairman and Commander-in-Chief of SPLM/SPLA presented detailed logistical and other necessary material support requests to the Derg government. Garang's list of request included armament (varieties of weapons), ammunitions, hand grenades and anti-personnel mines, uniforms, food, tracked bridge vehicles, sufficient quantities of fuel, oil and lubricants, communication radios and trucks. These material requirements were for thousands of trained SPLA forces to capture the six garrisons of Kapoeta, Torit, Bor, Mangalla, Akobo and Nasir; and to open new fronts in the North (Southern Kordofan and Southern Blue Nile), and in the South (Western Equatoria and Western Bahr el Ghazal). Logistical support request was also made to capture Kurmuk, "...for eventual attacks on Damazin and dislodge the OLF bandits from the area...." On 27 June 1987 Colonel Megistu Haile Mariam, the head of state of Ethiopia ordered the Minister of Defense and other high military officials to fulfill the 1987 logistics support request of John Garang. The ministry of defense estimated the cost of Garang's material requirements (the value of air lift and parachute not included): for ammunition Birr 74,438,875.00; weapons Birr 1,967,139.00; uniform Birr 2,707,700.00; vehicles \& radios 3,178,012.00; total Birr 82,287,726.00.22 For the year 1987 the quantity of war materials dropped by parachute from Antonov planes and helicopters at different places and times in South Sudan was 15,694.35 quintals, which required 315 flights. The furthest area was located $740 \mathrm{kms}$. away from the border, while the closest lay $300 \mathrm{kms}$. distance from the border. According to the Minister of Defense the frequent air lift of the logistical materials deep into South Sudanese territories had a political risk for the government, who complained that 'such decisions had to consider all political conditions, and the government could not fulfill all the requested weapons, ammunitions for small arms and uniforms'. ${ }^{23}$

\section{SPLA Military Progresses}

Once the leadership crisis in the SPLM/A was resolved, the primary task became the reorganization and arming of the remnants of Battalions 104 and 105 and the remaining elements of Anya Nya II, which now formed the nucleus of the SPLA. The first waves of recruits, mostly secondary school and university students and office workers were given intensive training at the Bonga camp and formed the Buffalo Battalion in 1983. The Jarad Division graduated in 1984, followed by the Mour Mour Division in 1985, the Kazuk in 1986, the Zalzal in 1987, the Intifaddha in 1988 and the Intisar in 1989. These were big

\footnotetext{
${ }^{21}$ MOND, ..4635, Tenth Year Operation Report, 1985.

${ }^{22}$ MOND, . .070, John Garang’s Memorandum 5 \& Logistic Requests, June 151987.

${ }^{23}$ Ibid.
} 
divisions of SPLA composed of more than fifteen thousand men including officers, who graduated from the main SPLA training camp in Bonga and the auxiliary training camps in Belpam, Dimma, and Buma. Unlike in a normal army formation, the SPLA squads consisted of 17 men, a platoon consisted of 51, while a company comprised of 224, and a battalion consisted of 1344 men. The SPLA grew rapidly in numerical and military strength. By 1991 it was between 100,000 and 120,000 strong, almost the size of the Sudanese government armed forces, excluding the air force and the navy. The SPLA had engaged the Sudanese army and its militias and scored remarkable victories (Nyaba 1997: 51).

Nevertheless, the period between 1983 and 1985 was a most critical moment in the life of the SPLA. The major obstacle was the presence of the Anya Nya II forces along the Ethiopian borders where the SPLA had set up its camps. These forces made it very difficult for the SPLA forces to come back to the Sudan across the border. The Anya Nya II obstructed the SPLA's attempts to carry out recruitment in Upper Nile and Bahr el Ghazal, and hundreds of thousands of recruits from these regions traveling to the training camps in the Gambella region of western Ethiopia were ambushed and massacred in 1984 and in 1986 by the Anya Nya II forces. Further more, some segments of the Anya Nya II forces defected to the Khartoum government and formed a special unit in the army and continued to fight against the SPLA. Moreover, the bloody split of the Anya Nya II between 1983 and 1988 which resulted in the loss of many lives was another challenge to the SPLA. The Anya Nya II split and the war with SPLA left deep scars among the people of south Sudan. The Anya Nya II split provoked a Dinka-Nuer ethnic animosity, which had serious repercussions for the civil population of the two groups in the Upper Nile. The split also adversely affected the development and military strategy of the SPLA. The split deprived the SPLA of the manpower it needed as the SPLA was depicted as a "Dinka movement" by the Nuer. This fit the propaganda of the Khartoum government which provided generous supplies of armaments to the Nuer forces in the Anya Nya II (Nyaba 1997: 16- 46).

The earliest SPLA military impact was felt at the end of 1983 when the first few guerrillas trained in the bases in Gambella crossed the border and kidnapped nine French and Pakistani engineers working on the controversial Jonglei Canal for four days and which eventually brought the project to a halt. In the same year the SPLA forces invaded Malwal town and destroyed the garrison. The world media broadcasted the incident, which publicized the emergence and struggle of the SPLA against Numeiri regime. ${ }^{24}$

The SPLA guerrillas mainly tried to inflict damage and capture equipment from the Sudanese army along the Sudan-Ethiopian border. In 1984 the SPLA began contacts with guerrilla units in distant areas such as Bentiu, Aweil, and Southern Kordofan. In these early days many recruits joined the SPLA not because of grievances with the North, but in order to get training and arms so that they could protect themselves from attacks of government militias organized among the Baqqara, Missiriya and Murle. The Bul Nuer took up arms to defend the Nuer against Missiriya incursions, and the Dinka recruits from northern Bahr alGhazal defended their territory from the Baqqara raids. The Sudanese government strategy of organizing tribal militias which began under Numeiri continued under the successive

${ }^{24}$ MOND, .691, /10/N25/ /1/6/76, 5 December 1984. 
governments in Khartoum (Johnson 2003 69). The militia strategy was to serve as a propaganda argument that the war in the South was the outcome of internal Southern tribalism (ethnic conflict). It enabled successive Khartoum regimes and its international supporters even to deny that there was a civil war in the Sudan at all.

By the end of 1985 the SPLA position inside the Sudan was strengthened by its capture of Boma, which became its headquarters, and its occupation of Yirol. Its important recruiting areas were the Upper Nile and Bahr al-Ghazal Regions. In Equatoria, the SPLA was by 1985 seen as a Dinka army and therefore had a few Equatorian recruits. Itang, Bonga, and Belpam in Gambella, in western Ethiopia remained the SPLA's main supply and training bases. By 1985 the SPLA had attacked the garrisons of Malakal and Nasir and sunk boats carrying 400 army forces on the White Nile. The SPLA guerrilla unit from Gambella destroyed the Wau bridge in Bhar al-Gazal and mined the road which destroyed tanks and trucks with soldiers. This guerrilla unit returned to Ethiopia with 17,000 recruits for training. South of Malakal the SPLA inhibited the movement of the army with tanks, trucks, and boats and most areas were accessible only by plane. At this point, the Saudi government interfered by sending four C130 planes to the Numeiri government to meet the military problem in the south. ${ }^{25}$

In 1985 and 1986 the army's heavy-handedness upon the civilians for alleged support for the SPLA increased SPLA's popularity throughout 1987 and 1988. In 1988 and 1989 many groups of local militias defected to the SPLA side. The defection of a large number of the Anya Nya II forces in 1988 in the Upper Nile and Jonglei was the most significant. Another important development for the SPLA was the increase in the number of recruits throughout the South, which gradually removed the characterization of the SPLA as a Dinka army. The SPLA moved the war further north into the Blue Nile, Southern Kordofan and Darfur. In these areas the SPLA received the sympathy and support of the non-Arab local populations who suffered attacks from Arab militias such as the Murahalin and the Rufa’a (Johnson 2003: 83-4).

\section{SPLA Activities in Gambella}

The atrocities committed against innocent people by the Anya Nya II forces backed by the Khrtoum government, desertions from and defections to the SPLA, and the general state of lawlessness that existed in eastern and central Upper Nile between 1983 and 1988 increased human rights abuses in the region. Cases of rape, murder, looting and burning of property and others were rampant and many of the crimes went unpunished. These crimes and chaotic conditions in the Upper Nile not only affected the south Sudanese, but also the Anuak and Nuer of Ethiopia in Gambela. According to Peter A. Nyaba, the SPLA recruits lacked political education and discipline and "Once they were deployed at the war front, their first victims became the unarmed civilians, whom they now terrorized, brutalized, raped, murdered and dehumanized.”( Nyaba 1997: 48-9)

The Derg and the SPLA cooperated with one another and the entire Gambella region was under a kind of their joint administration. The SPLA administered the refugee camps and was in charge of security around the border areas. The refugee camps were

${ }^{25}$ MOND, .731, Report of North Western and Western Command Fronts,1988. 
administered by committees consisting of 'representatives' of refugees, who were SPLA officers. The SPLA utilized relief goods intended for refugees to carry out its activities. The SPLA forces and the South Sudanese refugees enjoyed freedom of movement, while there were strict regulations imposed on the local communities of Gambella (Kurimoto 2005:339-358).

The presence of the SPLA in the region adversely affected every aspect of the life of the local population. The relation between the local Anuak and the SPLA was not friendly. The SPLA forces had committed considerable atrocities against the Anuak in some areas of Gambella. Theft, robbery, harassment, rape and killing by the heavily armed SPLA troops were common. In September 1989 the SPLA forces invaded the Anuak village of Pugnido, located along the Gilo River, near the refugee camp and, according to the elderly informants 120 Anuak were killed including women, children, the elderly and militias. The entire village was also burnt down. The attack was motivated in a revenge for the murder of a refugee by an Anuak. After four days the SPLA forces attacked Itang town and in the battle with the local militia near the refugee camp about 60 people were killed, 10 of them were SPLA men while the rest were the highlanders and the Anuak. In addition, the SPLA also killed about 14 people in Akado village near Itang town, where women and children were burnt in their tukul. According to the informants an unknown number of Anuak were killed by the SPLA in Gog-Jor district and were buried in mass graves. ${ }^{26}$ And all these crimes against the Anuak went unpunished. Another malicious action of the SPLA was their war on the people of Adini and Polkuni villages in Itang district, as the archives of the Ministry of Defense show:

This conflict was provoked by the members of the SPLA. They took the offensive on Polkuini village which they burnt. We came to understand that they forced the residents to flee across the river....The other SPLA segment which arrived from Mangog attacked Nor village and its inhabitants dispersed in the forest of the bank of the Baro river. They killed many people in launcher shelling....During the two battles many citizens were killed, 96 cattle were rustled, other properties taken...No food aid arrived for the people, so they are scattered to Jikawo and to unknown direction, houses and farms were burnt, households properties, sheep and goats, cows and calves had been driven to Berhane Selam by the SPLA....Unknown number of elders and children were killed. ${ }^{27}$

In May 1989 a meeting of Brigadier General Merid Niguse, the Chief of Staff of the Ethiopian armed forces and the top officials of the western provinces of Wallaga, Kaffa and Illu Ababor concluded that despite some efforts, it was impossible to stop the ruthless actions of the SPLA. Even after four years of this report, the SPLA disciplinary situation did not show any improvement, as the archives of the same office indicate:

\footnotetext{
${ }^{26}$ Informants: Abulla, David Odoro, Captain Bekele Badadda. (08 February 2007).

${ }^{27}$ Report of Gambella Officials to Ministry of Defence on the conflict between SPLA and people of Itang and Akobo, .438, Ref. No. 1/330/ 2, Tir 28, 1977 E.C.
} 
Some undisciplined SPLA members rustled the cattle of our citizens and also commit other criminal activities which created hostility with the people. Despite some efforts by the regional administration and SPLA leaders to correct the situation, the plan did not work as desired. ${ }^{28}$ It is necessary to disclose some of the irresponsible activities of 07 (SPLA) members to the higher authority so that its leadership may be given warning. ${ }^{29}$

According to an informant, David Oduro, the SPLA atrocities in Gambella could be attributed to the movement's strong desire to enlist the Anuak in the movement which the Anuak strongly resisted. According to the informants the SPLM/A's Anuak recruitment program and their involvement in the liberation struggle emanated apparently from the strategy of the movement to annex Gambella into the South Sudan and the iniquitous activities of the SPLA in Gambella were aimed at intimidation of the Anuak people in order to turn them to the movement. ${ }^{30}$ Even the armed officials of peasant associations resisted the misery and sufferings of the local communities by the SPLA, as the Gambella Regional Council archive states:

There is an intelligence report that from Quatguar area seven chairmen of peasant associations robbed school and clinic properties and defected to the Sudan with the objective of getting arms and ammunitions from the Sudan (government) and coming back to attack the refugees/SPLA with the people. ${ }^{31}$

Part of the atrocities of the SPLA against the Anuak in many villages could also be attributed to revenge against the GPLM guerrillas who enjoyed the support of the local people and killed many SPLA forces in Gambella. While the SPLM/A in its struggle against the domination and oppression of the regimes in Khartoum was significantly using the Derg, the latter had used the SPLA as a proxy against the opposition to the regime. Moreover, the Derg might have hoped that the SPLM/A victory in Southern Sudan or its seizure of state power in the whole of the Sudan would bring security to Ethiopia by avoiding any dissident working against Ethiopia from the Sudan.

\section{The Ethio-Sudan Proxy Wars}

The hostile Ethio-Sudan relations during1974-80 could be explained primarily by the intensification of the internal conflicts in both countries and the involvement of the two countries in international Cold War rivalries in the sub-region. The Soviet Union supplied

\footnotetext{
${ }^{28}$ MONDC .133onference on Security Problem in Western Ethiopia, Ginbot 3, 1973 E.C.

${ }^{29}$ MOND Rport of the Commander of Western Military Operation Headquarters, to the Chief of Staff, .438, Ref. No. . 1/330/ 2, Tir 28, 1977 E.C.

${ }^{30}$ Informants: David Odoro, Cham, Captain Bekele.

${ }^{31}$ MOD . 438 / /344/02/77, 23.05.1977
} 
arms to Libya, Ethiopia and South Yemen, while the USA supported Egypt, Sudan and Somalia. After the downfall of Numeiri in 1985 there was an increasing support for the Eritreans in the Sudan. Western and Arab support for the Eritrean rebels also increased through cross-border aid organizations such as the Eritrean Relief Association (ERA) which was established in 1975 and operated from bases in the Sudan. (Woodward 2003: 123)

The $14^{\text {th }}$ summit of the Leaders of the Organization of African Unity (OAU) set up a reconciliation committee consisting of seven countries to solve the conflict between the Sudanese and Ethiopian governments. The reconciliation committee met in Freetown in December 1977. On 18 June 1978 the foreign ministers of the two countries met in Dar es Salaam to talk on the improvement of Ethio-Sudan relations. In February 1979 the heads of state of the two countries came together through the mediation of Siaka Stevens, president of Sierra Leone and Chairman of the OAU at the time. ${ }^{32}$

These developments were followed by new peace initiatives by the government of the Sudan. It involved the Ethiopian government for talks on bilateral trade relations and for a meeting of the joint Ethio-Sudanese Ministerial Consultative Commission in Addis Ababa. The request was accepted by the Ethiopian government, leading to some improvements in their relations. The December 1979 report of the Ethiopian ambassador to the Sudan referring to these changes indicated that there was a halt of the propaganda support that the president and the high officials of the country gave to the Eritrean rebel groups. The Sudanese media also stopped their pro-Eritrean rebel propaganda and began to report on the positive aspects of the emerging new relations between the two countries after the long hostility from 1975 to $1980 .^{33}$

In the process of rapprochement between the governments, the two heads of states, Mengistu H/ Mariam and Numeiri exchanged visits and signed an agreement to close insurgent offices in their countries, to expel the rebel leaders from their respective regions and to close their common border to prevent the crossing of rebels from either side. To implement this they agreed to establish the joint Ethio-Sudan Defense and Intelligence Committee. At the Ethio-Sudan talks on defense issues the military government of Ethiopia requested the Sudanese government to cooperate in permitting its armed forces to use the Sudanese territory in order to cut the supply lines of the EPLF in an attempt to bring the northern war to an end. The Ethio-Sudan Sub-Committee on defense met on 16 June 1982 and agreed to consider ways and means of joint action regarding the prohibition of hostile activities directed against either country along the common border including air, ground and sea. This was in accordance with the provisions of the memorandum of understanding signed on 10 May 1982. The two governments agreed to exchange intelligence, instruct the military units and posts along the common border to prohibit any hostile penetration from either side, encouraging official contacts between the border posts to solve any local situation that might arise. ${ }^{34}$

\footnotetext{
${ }^{32}$ MOD, ..233, No. 1/516/9/10, 23/3/1972 E.C.

${ }^{33} \mathrm{MOD}, \quad$..018, 16 June 1982.

${ }^{34}$ MOD, ..233, Report of Ethio-Sudan Sub-Committee on Defence,16 June 1982.
} 
In the emerging positive relations, Ethiopia demanded from the Sudanese government to use Sudanese territory to block the roads used by the Eritrean rebels to penetrate into the Sahel region, Eritrea, as the military report in the archive of the Ministry of Defense indicated:

The strategy which would enable to defeat the rebels in the Sahel land is to block the communication lines from the Sudan to Eritrea and prevent the movement of provisions, fuel, medicine, and in general logistics to the rebels, which will result in their dispersal from their trenches.... ${ }^{35}$

In the case of response from the Sudanese government to its demands, the military government of Ethiopia had designed operational plans to block and control passages of logistics from the Sudan for the Eritrean rebels. In cooperation with the Sudanese armed forces, the Derg planned to deploy Ethiopian ground forces at the Sudanese territories of Arkiko, Tokar and Mama, Jelhante and Tabah valley to block the communication lines and gates to Nakfa and Sala in Eritrea used by the EPLF forces. The final Derg strategy was to wipe out the rebels from the Sudanese territories and to close the common border. The Derg continued its pressing demands on the Sudanese government in vain: the Sudanese government gave different excuses at different times. ${ }^{36}$ Thus the process of rapprochement between the two countries was frustrated and both continued not only supporting rebels from their neighbors, but also using them as proxies against one another.

\section{The SPLA Attacks on the OLF and the GPLM}

The SPLA repaid the assistance from Ethiopia by fighting proxy wars for the Derg against the OLF (the Oromo Liberation Front) and the GPLM (the Gambella People's Liberation Movement). Both movements were based in the Sudan and launched guerrilla wars against the Derg and SPLA from the Upper Nile and Blue Nile. The OLF which was founded in 1974 carried out armed struggle from Hararge in the east, and opened the western front in western Wallaga in 1978 bordering the Sudan. The discontent of the Oromo elite group which formed the OLF was traced back to Menelik's conquest of many territories of independent peoples, including the Oromo, in the south and south west in the early 1880s. Alien rule was imposed on the subjugated Oromo people who practiced the election of their own administrators through the gada system. The Oromo lost their ancestral land, most of which became "mengist" (state) land to be distributed at the will of the conquerors. Their labor was freely exploited by landlords. Occasionally they were expected to supply their landlords with fattened ox, ram, honey, butter, best grain and others. In addition, they paid the gibbir (taxes) and the tithes. (Baxter 1983: 133-4).

Many Oromo who lived in fertile territories were also transformed from free farmers into poor share-cropping tenants. Moreover, the Oromo were pressed to abandon their culture, tradition and religion in favor of the identity of the politically and economically

\footnotetext{
${ }^{35}$ MOD, ...233, Ethiopian Demands from the Ethio-Sudan Sub-Committee on Defence, 1983.

${ }^{36}$ Ibid.
} 
dominant group and were subjects rather than citizens of the Ethiopian empire. The subjugation and exploitation of the Oromo gave birth to the Oromo movement towards liberation. Until the final days of the imperial regime, the Oromo were denied any official status and were not allowed to publish, preach, teach or broadcast in their language. The important factors for the development of Oromo national consciousness were the consequences of the Imperial government's own creation of a strong, centralized administration which ignored local differences in custom and culture and the imposition of its own culture. These developments increased resentment and promoted feelings of nationalism. (Ibid).

In 1981 the headquarters of the OLF was 85 kilometers south of Kurmuk, along the bank of the Yabus river in the Sudan. Its camps and logistic stores were located at Kaburiya Yabus, Darsuma, Tasha, Camp 07 and Camp 08 in the Sudan. The OLF guerrillas carried out armed struggle against the Derg in Beni Shangul districts of Begi and Asosa, in Qellem districts of Gidami, Jimma Horro, Gawo Qebbe, Dalle Saddi, Dalle Wabarra, and Anfilo; and in Gimbi districts of Jarsso and Manasibu (Mandi). In some districts of Illu Ababor Region the OLF's work was limited to propaganda and recruitment activities. ${ }^{37}$ According to the military intelligence report, in western Ethiopia the OLF activities were a major problem comparable to what was happening in Eritrea and Tigray.

It appears that the on-going anti-revolutionary movement in Wallega Administration Regional Administration is worsening from day to day and changing its character. When the OLF's propaganda, recruitment and terrorist activities are closely assessed and evaluated, eventually the conditions that had been created in Eritrea and Tigrai would inevitably occur here. ${ }^{38}$

The materials in the archive of the Ministry of National Defense reflected the growing anxiety of the military authorities over the unprecedented surge of the OLF in western Ethiopia. One memo stated: "It is necessary to provide the required logistic support to the SPLA and in a coordinated operation with our armed forces to destroy the OLF camps in the Sudan."39

In the early 1980s both the OLF and GPLM were supported by the Sudanese army. The Khartoum government was well aware of the hostility between the SPLA and the Anuak of Gambella. The SPLA had frequently attacked OLF and GPLM camps, both in Ethiopia and the Sudan (Johnson 2001: 87-9; 2003:8). The GPLM was the movement of the Anuak of Gambella which had been formed under the Sudanese patronage in 1980 primarily by young Anuak fleeing conscription into peasant militias to fight in the northern war in the late 1970s. Another grievance of the Anuak was the increasing incorporation of Nuer into the local administration by the Derg. Moreover, the Anuak felt displaced from

${ }^{37}$ MOD, .416, Report on Security Conditions and threat areas of Illu Ababorr

Administrative Region, 1980.

${ }^{38}$ MOD, .116, No. 10/49/ /3/7/78, Report on the Security Condition in the Western Command Zone, 30/04/1978 E.C.

${ }^{39} \mathrm{MOD}, \quad .116$, From Chief of Staff of the Armed Forces to the Head of the Military

Operation Headquarters, 30/04/1978. 
their ancestral territories by the highland resettlement schemes and the Nuer settlement in Gambella since the inception of the civil war in southern Sudan in 1955. The Khartoum government was well aware of the bitter hostility between the SPLA and the Anuak of Gambella: 'the Sudanese government gave special consideration in embracing the Anuak to get intelligence information and eliminate the SPLA movement' ${ }^{40}$ The research on the ethnic groups of Gambella by the army officer in charge of the SPLA shows Derg's repugnance for the Anuak. ${ }^{41}$

On 24 March 1987 the GPLM guerrillas infiltrated into Gambella district from Anfillo district of Qellem and invaded the Baro Abol Resettlement Camp killing five settlers and burnt crops, fertilizers and some houses. On 2 April 1987 they ambushed workers who were engaged in road construction and killed six of them and took away five workers. On 23 March 1987 the GPLM forces attacked the police and the militia at Jor district killing fifteen of them. In the meantime from 7 February 1987 for a continuous 47 days the SPLA carried out relentless attacks against the Sudanese forces in an attempt to capture the Sudanese Jikawo. However, the heavily armed Sudanese reinforcement forces arrived and forced the SPLA guerrillas to retreat to Gambella. The Sudanese army crossed the border in pursuit of the SPLA forces and destroyed the Ethiopian Jikawo town and the police station. The Sudanese forces penetrated $15 \mathrm{kms}$. deep into Gambella and pillaged whatever property they could take and burnt down the rest. ${ }^{42}$

In Gambella, for the first time the Ethiopian army and the SPLA combined their forces and liberated the Ethiopian Jikawo from the Sudanese army. As the archives of the Ministry of National Defense reveals: "Based on the order given from the higher authority, the Ethiopian Jikawo was liberated after the fighting on 18 April 1987, and under the leadership of John Garang, the commander of the SPLA, in an astonishing coordination and leadership after five days of fighting the Sudanese Jikawo was captured on April 22, 1987.",43

The SPLA fought along with the Ethiopian army against the large-scale EPLF-OLF invasion of Asossa in 1990 and against the Sudanese forces which frequently attacked the Ethiopian Akobo and other border districts in the Gambella region. On the other side, the Ethiopian army had been accused by the Sudanese government for involvement in the brief capture of the northern Sudanese towns of Kurmuk and Geissan by the SPLA in 1987 (James 2007: 53).

The SPLA's military success against the OLF at the beginning of 1985 brought it almost unlimited military and logistical support from the Derg regime and cemented the personal alliance between Colonel Mengistu and John Garang. The SPLA dislodged the OLF forces and destroyed their camps in areas known as Daga, Pant and Zakor in Southern Blue Nile. The OLF forces reorganized and consolidated themselves in a region called

${ }^{40} \mathrm{MOD}, \quad .133$, Conference of high officials on Security problems in the Western Administrative Regions, May 3, 1981 E.C.

${ }^{41}$ MOD, .131, No. /4382/j / /37/11/82, Captain Teshome Shaqutie, "The Survey of the

Anuak, Nuer, Majanger, and Opo Ethnic Groups of Gambella Adm nistrative Region”, 15/12/1982.

${ }^{42}$ Informants: David Odoro, Cham Ujulu,

${ }^{43}$ MOND, .416, Security Conditions of Illu Ababor Administrative Region, 1980 E.C 
Tasha in Begi district in western Wallaga. From Tasha the OLF infiltrated into Begi and succeeded in getting the support of the local population, and 562 leaders of mass organizations had joined it. The OLF also successfully cut Begi's economic, social and administrative links with Asossa town. The SPLA provided all the necessary intelligence information about the OLF to the Derg authorities and by the end of June 1985 participated in the battle of Tasha against the OLF. During the fighting 250 houses, 150 small market shops, seven peasant association offices with their halls, ten peasant villages, two big stores and the main camp of the OLF with ammunitions and provisions were completely destroyed. The SPLA had played a great role in the victory over the OLF which retreated and set up its camp at Giessan in the north. ${ }^{44}$

\section{The 1989-90 EPLF-OLF Invasion of Asossa}

The Sudanese army had also supported the 1989-90 EPLF-OLF invasion and prolonged occupation of Assosa. The Archives of the Ministry of National Defense stated:

From January 24, 1990 onwards, our army stationed at Agobela, Kurmuk, Giessan and Qotta Warqe, quit communication and it is also impossible to make radio communication through the Police and the SPLA. The simultaneous attacks on the Ethiopian Kurmuk and Angobela were beyond the capacity of our army which led to its disarray. The invaders were the EPLF and OLF forces, and the EPLF constituted the larger number. Both used our army uniforms. The Sudanese army had participated in the attacks on Kurmuk and Qotta Warqe ${ }^{45}$.

The coordinated EPLF-OLF invasion of Asossa was organized by the Sudanese army and the EPLF in Demazin. In its efforts to weaken the Derg, expand the war and support opposition to the Derg, the EPLF moved south and captured Beni Shangul. It left the territory to the OLF which was assumed to have local popular support and ethnic affinity with the local people. The OLF could only hold Beni Shangul for two months and before it retreated it destroyed the local power station, the hospital, and took valuable items that it could carry away (Young 1999:327).

The border towns of Kurmuk and Giessan and Agobela village were occupied by the rebels supported by the Sudanese army. From Agobela the EPLF-OLF forces marched to Asossa town which they controlled on 5 January 1990. The EPLF-OLF coalition forces were engaged in heavy fighting against the 'Fourth Revolutionary Army' of Ethiopia at Tsore, where the Uduk refugee camp and SPLA training base was located and at the Mountain of Arsis, on the entrance of the town. The invading forces marched further to the interior and controlled the town of Bambasi and at the bridge of the Dabus river hand to hand combat took place which resulted in heavy loss of life from both sides. The bridge was destroyed and the Ethiopian army retreated to Mendi (Manasibu) district, found at about 230 kms. from Kurmuk. In Mendi the rebels destroyed the Dalati Ethio-Libyan Marble industry. The intention of the assistance of Sudanese army for the rebels was to

${ }^{44}$ MOD, . .438, No.3/ / /22/6/008/77, 02/11/1977.

${ }^{45}$ MOD, .344, ZS4 10/ /ZT2/1702/82, Report of Fourth Army Division, December 13,1990. 
dislodge the SPLA from Kurmuk, which was captured in September 1989. The Sudanese government also planned the destruction of the Tsore refugee camp and the SPLA military training camps found in the region. During the EPLF-OLF attacks in the Asossa area, the SPLA had about 4000-6000 forces at its training camps of Giessan, Qotta Warke, Jebel Dul and Camp No.47. The SPLA forces and thousands of refugees from the Blue Nile left Asossa through Megele and Shirkole to Gambella. Asossa town was occupied from 5 January 1990 to 3 February 1990 by the OLF forces. ${ }^{46}$

By the time the government reorganized the dispersed forces to take an offensive through 'Zemecha Tireg', literally, 'Operation Wipe Out/Eliminate'; the rebels had already left Asossa to the Sudanese border. The Ethiopian government could not deploy sufficient forces to secure the Asossa front which experienced unprecedented large-scale invasion because of heavy military engagement against the EPLF in the north and against the fast advancing and successful military operations of the EPRDF forces in the central provinces. John Garang's 5 January 1991 logistical requests to the Derg showed that the Sudanese government had massed troops in Malakal, including two Brigades of various Ethiopian rebel groups (OLF, EPLF, GLF (GPLM) etc.) for eventual attacks on Gambella and Itang. ${ }^{47}$ The Ethiopian military authorities not only gave a prompt response to Garang's logistics request by supplying arms, ammunition, communication radios and provision, but also made preparations for military support to the SPLA. The Ethiopian army occupied strategic points on the Ethio-Sudan border and Lt. General Addis Tedla, the General Chief of Staff of the armed forces ordered the Ethiopian Air Force to provide air support for the movement. ${ }^{48}$

According to the military report, large attacks were planned on Gambella from two directions by the OLF-GPLM forces. The desperate situation compelled the Ethiopian military authorities to press on the SPLA to participate in the intensifying wars against the opposition movements. Nevertheless, the SPLA chief in Addis Ababa was requested by the Ethiopian officials to contribute to the intensification of fighting against the opposition movements. Amidst the increasing military operation, the Derg government continued urgent logistic supplies for the SPLA ${ }^{49}$. The 1990s intensified attacks from the different regions of the country had brought about alarming challenges of unprecedented proportion in the military, political and diplomatic fronts for the military regime of Ethiopia, which eventually led to its demise. The collapse of the Derg was immediately followed by the withdrawal of the SPLM/A and south Sudanese refugees from Ethiopia.

\title{
Conclusion
}

\author{
46MOD, .344, ZS4 10/ /ZT2/1702/82, Report of Fourth Army Division, December 13,1990. \\ 47MOD, ..627, 10- 07/N52/ /763/83, January 10, 1991. \\ 48MOND .. 265, Ref. No. 10- 07/1417/ /802/83 \\ ${ }^{49}$ MOND . 280, Ref. No. 10- 07/ 52/ /763/83
}


In the1990s the Horn of Africa region witnessed multiple dramatic events including: the EPRDF seizure of power in Ethiopia toppling the Derg government, the fall of Siyad Barre in Somalia and the collapse of the state, the emergence of Eritrea as an independent state, SPLA's sudden withdrawal from Ethiopia, the evacuation of thousands of Southern Sudanese refugees from southwestern Ethiopia, and the inauguration of new friendly relations between the EPRDF and the Sudanese government. The year 1991 also marked the end of the Cold War and a radical change of perspectives in Western countries on the developing countries with consequences for the regional political configuration of the Horn of Africa.

After 1991 the pattern of conflict along the Ethiopian border territories, especially in the Gambella region assumed a new phase. The Anuak and the Nuer comprise the two largest ethnic groups of Gambella and they dominate the politics of the Gambella Regional State. The post-1991 political process of the region was shaped by the social interaction and political relations between the two traditional enemies, the Anuak and the Nuer. On 16 May 1991 the combined forces of the EPRDF and GPLM drove out the Nuer Derg officials of Gambella and the SPLA forces. The alliance between the EPRDF and the GPLM during the armed struggle enabled the Anuak to take control of the Gambella region.

The new federal administrative arrangement transformed Gambella from frontier district into a regional state, the 'Gambella People's National Regional State' (GPNRS). The Gambella Regional State is one of the nine regional states of the Federal Republic of Ethiopia. After the establishment of the Gambella Regional State and the rise of new power structure new patterns of relations emerged between the Anuak and the Nuer. There were disagreements over the level of representation of the two ethnic groups in higher offices of the region. Issues related to sharing of resources also complicated relations between them ( Asnake 2004). The magnitude of the Anuak-Nuer conflict indicated the past hostilities, issues of political representation and competition over the resources of the region. The Regional Government of Gambella was dominated by the GPLM, the Anuak organization which claimed that Gambella was an Anuak land. The new Anuak rulers accused the Nuer for designing the atrocities committed against the Anuak community by the SPLM/A. In the June 1992 election for the Regional State Council of Gambella, among the twelve Council members seven were Anuak and there were no Nuer elect to the Regional Council, as elections did not take place in the Nuer districts of Akobo, Jikawo and Itang because of security reaons. Therefore, the Anuak-GPLM dominated the Regional Council, and the majority of appointed vice-ministers of the Regional Government were also the Anuak (Dereje 2002).

Eventually the Anuak took over the political offices and administrative posts. The presidency and other higher positions in the regional council were reserved for the Anuak which reflected the Anuak domination. The pattern of power distribution remained that an Anuak president, a Nuer vice-president, and a Majenger secretary. The Anuak dominance was revealed in their higher representation in the council and employment opportunities in the emerging regional bureaucracy. In 1992 out of 20 regional ministers there were 15 Anuak, 3 Nuer, 1 Majenger and 1 Komo. After a decade, out of 18 ministers there were 11 Anuak, 6 Nuer and 1 Komo (Goma). (Dereje 2006) 
The Anuak political dominance was contested by the Nuer who constituted the subordinate political status in the regional politics. In 2003 the Anuak-Nuer deadly conflict called for the intervention of the federal government. The federal government introduced a new power-sharing arrangement through ethnic-based zonal administration which created an equitable representation and a greater inclusion of the Nuer in the regional politics. The Anuak politicians, however, considered the new power sharing as a threat to their dominance. The Anuak-Nuer violent conflict eventually subsided by the late 2003, but a relative peace in Gambella was very brief as ethnic conflict between the Anuak and the highland communities of the region was emerging which culminated in the 13 December 2003 massacre of the Anuak. The various groups in Gambella could not emerge as partners but competed for political power and engaged in conflicting strategies of ethnic entitlement which generated violent conflicts. The federal experiment in the GPNRS exhibited serious challenges, and Dereje had this reaction to the process, "....Ironically, a policy which was hailed as a means of promoting inter-group harmony has resulted in just the opposite." (Dereje 2002:24)

The continued mutual and reciprocal harbouring and supporting of opposition insurgent groups fighting to overthrow their respective governments had adversely affected relations between the Sudan and Ethiopia. The TPLF had enjoyed strong backing from both Numeiri and Al-Bashir regimes during its armed struggle against the Derg as a counter balance for the generous military and logistical support the latter provided to the SPLM/A. When the EPRDF seized power the National Islamic Front (NIF) government believed that a greater opportunity was created to wipe out the SPLA. On the other hand, the EPRDF was eager to establish friendly relations with the Sudan as a positive gesture to pay back what it owed the country. In 1992 Ethiopia and the Sudan signed a friendship agreement which included the opening up of their boundaries for the free movement of people and goods. The two countries also agreed to expel opposition groups operating in their territories. This agreement was very important for both governments because it would deprive the SPLM/A of any future assistance from Ethiopia which would provide a good opportunity for the NIF government to gain the upper hand in the war in Southern Sudan. With regard to Ethiopia, the agreement could avoid the involvement of the Sudan in assisting any insurgent movement that might threaten the young EPRDF regime. This was evident in the withdrawal of the OLF from the Transitional Government in opposition to the 20 June 1992 local elections which made the Ethiopian government committed to maintain its friendly ties with the Sudan. It was also at this time that the Ethiopian government allowed the opening of the Sudanese government consulates in Gambella and Assosa towns. (Molla 2002:28)

New conflicts are predicted in Gambella with the beginning of oil exploration in the region after the agreement between the federal government of Ethiopia and Petronas, a Malaysian based company. This company also exploits oil fields in southern Sudan. While the exploration is underway, different ethnic and political groups have already claimed rights and access to exploring and benefiting from the natural resources. Under the title "To whom does Ethiopia's Gambella oil belong? the Sudan Tribune recorded that "Gambella is an extension of the Mulet basin, located in south Sudan, and is known for its huge amount of oil reserve.” (Sudan Tribune 2006) One of the outstanding issues in the Comprehensive 
Peace Agreement between the Government of the Sudan an the SPLM/A on 9 January 2005 was the referendum of 2011 in southern Sudan for unity or independence, which brought the long civil war to an end. A survey recently conducted in most parts of southern Sudan indicated that over 90\% southern Sudanese interviewed said they would vote for independent south Sudan. However, the National Congress Party (NCP) put many obstacles against the referendum. (David Nailo Majo 2009). Nevertheless, an independent south Sudan would be perceived as a potential threat to other countries dependent on the waters of the Nile, particularly Egypt. Confrontation also may occur between independent south Sudan and the Gambella Regional State which is undertaking irrigation schemes in the Baro-Akobo basin, which may complicate regional politics. A civil war in the south is projected if problems between the north and south are not resolved prior to the referendum. This would reverse the relative peace of the Gambella region as civil war in southern Sudan will cause another round of influx of refugees into Gambella.

\section{References}

Asnake Kefale. 2004. Federalism: Some Trends of Ethnic Conflicts and their Management in Ethiopia. In Alfred G. Nhema, editor. The Quest for Peace in Africa. OSSERA, Addis Ababa.

Baxter, Paul T. W. 1983. The Problem of the Oromo or the Problem for the Oromo. In Lews, I. M., editor, Nationalism and Self-Determination in the Horn of Africa. London: Ithaca Press, pp. 129-149.

David Nailo Majo. 2009. Unilateral Declaration of Independence: Recent Cases and Lessons for Sudan. The Proceedings of International Sudan Studies Conference, University of South Africa, Pretoria.

Dereje Feyissa. 2006. The Experience of the Gambella Regional State. In Turton, David, editor. Ethnic Federalism: The Ethiopian Experience in Comparative Perspective. Oxford: James Currey - Athens, OH: Ohio University Press- Addis Ababa: Addis Ababa University Press, pp. 208-230.

2006. Ethnic Federalism and Conflicting Political Projects: The Case of AnywaaNuer Relations in the Gambella Regional State. Proceedings of the $15^{\text {th }}$ International Conference of Ethiopian Studies ed., Siegbert Uhlig. Harrassowitz Verlag Wiesbaden, pp. 953- 960.

Hutchinson, Sharon E. 2001. A Curse from God? Religious and political dimensions of the post -1991 rise of ethnic violence in South Sudan. Journal of Modern African Studies, 39 (2) 307-331.

James, Wendy. 2007. War and Survival in Sudan's Frontier lands, Voices from the Blue Nile, Oxford: Oxford University Press.

Johnson, Douglas H. 2003. The Root Causes of Sudan's Civil Wars. Indiana: Indiana University Press.

2001. The Nuer Civil War. In Maji-Britt Johnnsen and Niels Kasfelt, editors. Sudanese Society in the Context of Civil War. Copenhagen. 
Kurimoto, Eisei. 1997. Politicization of Ethnicity in Gambella Region, In Katsuyoshi Fukui, $\quad$ E. Kurimoto \& M. Shigeta, editors, Ethiopia in Broader Perspectives, vol. II, Proceedings of the $13^{\text {th }}$ International Conference of Ethiopian Studies, Kyoto, Shokado, pp. 798-815.

2005. Multidimensional Impact of Refugees and Settlers in the Gambella Region, Western Ethiopia, In Itaru Ohta and Yntiso D. Gebre, editors. Displacement Risks in Africa: Refugees, Re-settlers and their Host population, Kyoto University Press, Kyodai Kaikan, pp. 339-358.

Molla Mengistu, 2002. "Ethio-Sudanese Relations: 1991-2001", MA Thesis in International Relations.Addis Ababa University.

Nyaba, Peter A. 1997. The Politics of Liberation in South Sudan, An Insider's View. Kampala: Fountain Publishers,

Sudan Tribune, No. 12, 2006.

Wakoson Elias N. 1987. The Sudanese Dilemma: The South - North Conflict, Northeast African Studies, Volume 9(3) 43-58.

Young, John. 1999. Along Ethiopia's western frontier: Gambella and Benishangul in transition. The Journal of Modern African Studies 37(2) 321-346. 